\title{
A economia da Rússia no século 21: as dinâmicas da ascensão econômica e da relativa estagnação após a crise global de 2008
}

\author{
The economy of Russia in the $21^{\text {st }}$ century: \\ the dynamics of economic rise and the relative \\ stagnation after the global crises of 2008
}

DOI: $10.21530 /$ ci.v13n2.2018.768

Rafael Henrique Dias Manzi ${ }^{1}$

\begin{abstract}
Resumo
O desempenho da economia da Rússia na primeira década após o esfacelamento político da União Soviética foi marcado por instabilidades macroeconômicas e por uma profunda recessão econômica. Esse cenário reverteu-se a partir do início do século 21 quando o país entrou em um novo ciclo de expansão econômica marcada por uma expressiva aceleração das taxas de crescimento do PIB. Contudo, a partir da década de 2010, a economia russa perdeu dinamismo e o processo de convergência de renda com os países desenvolvidos estagnou-se novamente. O principal objetivo do artigo é fazer uma análise do processo de ascensão econômica da Rússia e do atual quadro de relativa estagnação a partir da eclosão da crise global de 2008. Os resultados apontam que o quadro de relativa estagnação da economia da Rússia não está ligado somente a fatores conjunturais, como a queda dos preços das commodities energéticas nos mercados internacionais e o acirramento das tensões geopolíticas com o mundo ocidental, mas refletem também, em grande medida, fragilidades domésticas da economia russa.
\end{abstract}

Palavras-chave: Rússia; Economia Internacional; Superciclo de Commodities; Petróleo; Geopolítica.

\footnotetext{
Abstract

1 Doutor em relações internacionais pela Universidade de Brasília - UnB.

Artigo submetido em 26/02/2018 e aprovado em 26/07/2018.
}

The performance of Russia's economy in the first decade after the break-up of the Soviet Union was marked by macroeconomic instabilities and a deep economic recession. This scenario reverted from the beginning of the $21^{\text {st }}$ century when the country entered a new cycle 
of economic expansion marked by a significant acceleration of GDP growth rates. However, from the decade of 2010 the Russia economy registered an economic growth slowdown and the process of income convergence within the developed countries stagnated again. The main objective of the article is to analyze the process of economic growth in Russia and the current situation of relative stagnation after the outbreak of the global crisis of 2008. The results indicate that the relative stagnation of Russia's economy is not only related just to conjuncture factors, such as the fall in the prices of energy commodities in the international markets and the intensification of geopolitical tensions with the Western world, but also reflect to a great extent, domestic weaknesses of the Russian economy.

Keywords: Russia; International Economics; Commodities Supercycle; Oil Crude; Geopolitics.

\section{Introdução}

A queda do muro de Berlim (1989) e o esfacelamento político da União Soviética (1991) colocaram fim à ordem bipolar que caracterizou a dinâmica geopolítica do sistema internacional a partir do fim da década de 1940. Nesse período, os Estados Unidos e a União Soviética disputaram a hegemonia do sistema internacional do ponto de vista geopolítico e econômico. O conflito geopolítico e econômico (capitalismo x socialismo) estendeu-se pela América Latina, África, Ásia e Europa e foi caracterizado pelo confronto indireto por áreas de influência entre as duas superpotências globais (FRIEDEN, 2008).

Com o fim da Guerra Fria, na década de 1990, o status da Rússia de superpotência do sistema internacional chegou ao fim com o surgimento de uma nova ordem internacional marcada inicialmente pela hegemonia das democracias de mercado ${ }^{2}$. No aspecto econômico, os anos de1990 foram marcados pela transição da Rússia para uma economia de mercado e por uma profunda crise econômica. Essa conjuntura passou a ser alterada a partir do início da década de 2000, quando a Rússia registrou elevadas taxas de crescimento econômico. Isso não sugere que o país reconquistou o espaço ocupado no período da Guerra Fria, mas que o crescimento da economia russa reverteu enormemente o processo de declínio registrado pela Rússia ao longo dos anos de1990. Contudo, a partir do início da década de 2010, a economia russa começou a demonstrar sinais de fragilidade em virtude da forte desaceleração das taxas de crescimento do PIB, que culminou em uma recessão econômica no biênio 2015/2016.

2 Sobre o conceito do termo hegemonia das democracias de mercado ver Viola; Leis (2007). 
O principal objetivo do artigo é examinar a conjuntura da economia da Rússia com o intuito de examinar as variáveis que explicam tanto o processo de aceleração das taxas de crescimento a partir do início da década de 2000 quanto o quadro de relativa estagnação a partir da eclosão da crise global de 2008. O argumento central do artigo é de que as dinâmicas internacionais, principalmente no tocante à evolução da demanda e dos preços das commodities energéticas é uma variável fundamental para compreender o processo de ascensão da economia da Rússia a partir do fim da década de 1990. Contudo, o quadro de relativa estagnação da economia da Rússia a partir da década de 2010 é reflexo de fragilidades domésticas ligadas principalmente ao baixo nível de diversificação produtiva, à estagnação dos indicadores de produtividade e eficiência econômica e também relacionada aos níveis insuficientes de investimentos domésticos.

Do ponto de vista da metodologia empregada, o argumento central do artigo é construído a partir da sistematização de variáveis estruturais e conjunturais que explicam o desempenho da economia da Rússia a partir do fim da década de 1990. Em virtude da importância do setor de petróleo e gás natural, a evolução dos preços e da demanda internacional por commodities energéticas constitui-se na principal variável que afeta o desempenho de curto prazo da economia russa. Ao mesmo tempo, serão identificadas e analisadas as variáveis domésticas que estão relacionadas ao quadro de relativa estagnação da economia da Rússia em virtude da incapacidade do país em acelerar o processo de diversificação e modernização produtiva. Em relação aos aspectos domésticos, destacam-se : a adoção de políticas econômicas que resultaram no aprofundamento das relações de crony capitalism com reflexos negativos sobre os níveis de produtividade e eficiência econômica; disfuncionalidades do setor financeiro que reduzem a disponibilidade de recursos para investimentos domésticos e; fragilidades institucionais no tocante aos direitos de propriedade que acabam por gerar desincentivos para a realização de novos investimentos produtivos. Esses dados serão construídos a partir da bibliografia já existente e também da interpretação de fontes primárias e secundárias.

Nessa perspectiva, o artigo é dividido em três seções. Na primeira, examinaremos as dinâmicas econômicas na primeira década após o fim da Guerra Fria e os fatores que explicam a ascensão econômica da Rússia a partir do início do novo milênio. Na segunda, discutir-se-á a performance da economia russa a partir de 2008 e como dinâmicas relacionadas ao fim do superciclo das commodities internacionais e do acirramento das disputas geopolíticas da Rússia com o mundo ocidental têm impacto sobre a economia russa. Na última seção, serão analisadas as variáveis 
domésticas que explicam porque, apesar da expansão da renda ao longo do superciclo das commodities internacionais, não ocorreu um processo de maior diversificação e modernização da economia da Rússia.

\section{A economia da Rússia no pós-Guerra Fria: da década "perdida” aos anos doutorado de 2000}

Quando Mikhail Gorbachev ascendeu ao cargo de secretário-geral da União Soviética, a economia soviética já não apresentava mais o mesmo dinamismo das décadas de 1950 e 1960. Nesse período, aventou-se inclusive a possibilidade de que o desempenho da economia soviética iria transformar o país na maior economia do mundo, superando até mesmo os Estados Unidos (JOFFE, 2014). A partir de meados da década de 1970, a performance da economia soviética já não era mais a mesma em virtude do baixo dinamismo econômico do país. Entre 1975 e 1985, por exemplo, a taxa média de crescimento da União Soviética caiu para patamares inferiores à $2.5 \%$ ao ano (OFER, 1987).

A desaceleração da economia da União Soviética era um sintoma da exaustão do modelo de crescimento econômico baseado principalmente no acúmulo de capitais. Como observa Ofer (1987, p. 1814-1815), a perda de dinamismo da economia soviética a partir da década de 1970 está relacionada a três fatores:

\footnotetext{
"Primeiro, o crescimento extensivo é, por natureza, exaurível, à medida que existe um processo de próprio declínio da própria produtividade do capital. Em segundo lugar, a mudança tecnológica e a melhoria da eficiência não ocorreram de modo suficiente para acelerar o crescimento dos indicadores de produtividade. Na verdade, a contribuição da tecnologia declinou ao longo dos anos, refletindo a crescente dificuldade de adquirir tecnologias mais eficientes do ocidente. Finalmente, o declínio do crescimento foi acelerado em virtude da estratégia adotada pelas autoridades soviéticas de acelerar a convergência de renda do país com o mundo ocidental ter chegado ao seu limite em virtude da estagnação da produtividade econômica3”".
}

\footnotetext{
3 "First, extensive growth is by nature exhaustible, as manifested in the unavoidable decline in the growth rates of inputs. Second, technological change and improved efficiency failed to replace in replace input growth, in fact, the contribution of technology declined over the years, reflecting the increased difficulty of borrowing Western technologies cheaply. Finally, the decline growth was accelerated by the strategy of haste. Haste not only made the growth curse decline more steeply but has also been partly responsible for the difficulties encountered by the Soviet economy is shifting to an intensive path."
} 
É dentro desse contexto de fragilidades econômicas que ascende, Mikhail Gorbachev, ao cargo de secretário-geral do partido comunista. Mikhail Gorbachev assumiu com a principal missão de instaurar reformas econômicas com o intuito de elevar as taxas de crescimento econômico da já cambaleante economia soviética. Tanto a perestroika quanto a glasnost tinham como objetivo enfraquecer o controle do partido comunista sobre a sociedade, mas não ocasionar um colapso econômico e político da União Soviética ${ }^{4}$. Ou seja, as reformas econômicas tinham como ponto central dinamizar a economia soviética, mas com o propósito de impedir uma crise política que colocasse em risco o próprio regime comunista, o que acabou de fato ocorrendo a partir dos eventos que culminaram na crise do comunismo soviético no início da década de 1990.

Mesmo que relativamente tímidas, as reformas do período Gorbachev reduziram a centralização econômica, incentivaram a criação de joint ventures com a participação de empresas estatais e legalizaram a existência de cooperativas privadas. Em junho de 1987, o governo russo promulgou a Law of State Enterprise para reduzir o planejamento central da economia da União Soviética. A lei autorizou empresas a venderem produtos a preços de mercado e o fechamento de empresas que eram consideradas pelo governo russo como ineficientes. Outra medida para reduzir o controle estatal foi à criação da Lei das Cooperativas em 1988. Nesse caso, o governo russo permitiu a formação de empresas para a exportação de commodities que tinham os preços, anteriormente ao início das reformas econômicas, controlados pelas autoridades políticas de Moscou. Além disso, a criação da Law on Leasing de 1989 possibilitou aos funcionários das estatais realizarem operações de leasing e compra das empresas estatais. (LETICHE, 2007).

As reformas impetradas pela nova administração acabaram por desgastar e enfraquecer ainda mais o regime político e culminou na crise do comunismo soviético. Na década de 1990, as reformas econômicas intensificaram-se principalmente no tocante a transferências dos ativos públicos para o setor privado. O processo de privatização teve duas fases. Na primeira, o programa de privatização das empresas estatais russas teve início em outubro de 1992 e foi finalizado em junho de 1994. Nesse período, aproximadamente $70 \%$ das empresas estatais de grande e médio porte e $90 \%$ das pequenas companhias foram transferidas para o setor

4 O termo glasnost é de origem russa e significa abertura. Foi designado para representar o processo de reforma política na União Soviética que representou a redução do poder do partido comunista e a realização de eleições multipartidárias. A perestroika é também um termo russo, mas tem uma conotação mais voltada a economia que pode ser entendido como "reestruturação” econômica e liberalização econômica. 
privado. Já a segunda fase ocorreu ao longo de 1995 e 1996, sendo caracterizada pela venda direta de empresas estatais ao setor privado por meio de initial public offerings (IPOs). Quando o programa de privatização da Rússia chegou ao fim, aproximadamente $70 \%$ do PIB, já estava sob o controle do setor privado. (VINHAS DE SOUZA, 2007).

O processo de transição para uma economia de mercado na Rússia gerou desequilíbrios econômicos decorrentes do descasamento entre oferta e demanda que se refletiram na profunda crise econômica da década de 19905. Entre 1992 e 1999, por exemplo, o PIB per capita russo teve uma contração próxima de $25 \%$. As fragilidades econômicas decorriam principalmente das elevadas taxas de inflação, desequilíbrios fiscais e vulnerabilidade externa em virtude da excessiva valorização do rublo russo e do baixo nível de reservas internacionais. Além disso, as instabilidades econômicas em outros mercados emergentes da década de 1990, como as crises financeiras no México (1994) e Ásia (1997), contribuíram para elevar as percepções de riscos na solidez das economias emergentes e da própria Rússia. A combinação entre fragilidades macroeconômicas domésticas e instabilidades nos mercados financeiros acabou por culminar na eclosão da crise financeira de 1999 (FRIEDEN, 2008).

O período de estagnação econômica fica mais evidente a partir da evolução dos indicadores de renda da economia da Rússia. A Figura 1 demonstra a evolução da renda per capita da Rússia em Paridade de poder de Compra (PPC) em comparação aos Estados Unidos, Japão e Alemanha. O PIB per capita em PPC russo registrou significativa redução em relação à renda de um residente nos Estados Unidos, Alemanha e Japão a partir do início da década de 1990. Em relação aos Estados Unidos, por exemplo, a renda per capita da Rússia declinou de aproximadamente $45 \%$ da renda estadunidense, em 1992, para $30.6 \%$ no ano de 2000.

5 Esse fenômeno decorreu, por exemplo, da existência de uma significativa alocação de capitais e recursos humanos para o setor militar durante o período da União Soviética. Com o fim da Guerra Fria e a redução dos gastos militares, houve uma significativa redução da demanda de bens ligados ao setor de armamentos. Assim, setores que eram ligados diretamente ou mesmo indiretamente ao complexo militar tiveram forte redução da demanda por seus bens, o que contribuiu para reduzir a própria capacidade produtiva da economia da Rússia. 
Figura 1. Percentual do PIB per capita em PPC da Rússia em relação à renda per capita dos Estados Unidos, Alemanha e Japão

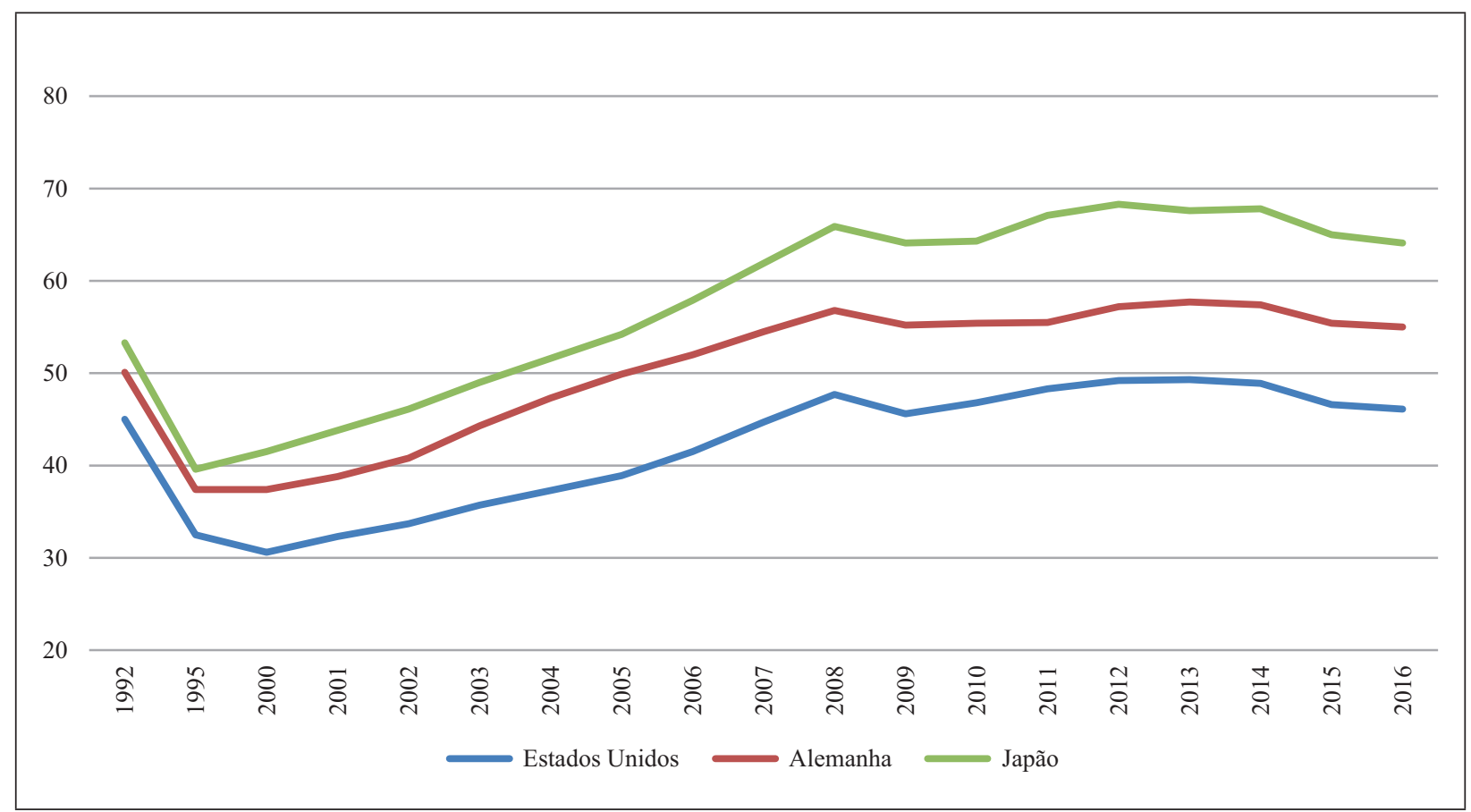

Fonte: FMI, 2018a.

Esse processo de declínio econômico da Rússia chegou ao fim a partir do fim da década de 1990, quando o país entrou em um novo ciclo de expansão econômica. O PIB da Rússia, entre 1999 e 2008, registrou crescimento médio de $6.8 \%$ ao ano - acima do observado na economia mundial ( $4.2 \%$ ao ano) e mesmo superior ao das economias emergentes e pobres (6.1\%). Nesse mesmo período, a renda per capita em PPC da Rússia mais do que dobrou, passando de US\$9.889 para US\$ 23.047. Esse fenômeno é também captado na Figura 1, que demonstra a reversão de declínio econômico da Rússia em relação ao mundo desenvolvido, pelo menos até a eclosão da crise global de 2008.

O período de transição e recuperação da economia russa, depois da profunda recessão econômica da década de 1990, pode ser dividido em três fases. Na primeira, que tem início no fim de 1998 e vai até o fim do primeiro semestre de 1999, a recuperação econômica decorreu em grande medida da melhora da competitividade artificial (já que foi por meio do câmbio) da Rússia em virtude da desvalorização do rublo. Por um lado, a redução de perto de $50 \%$ das importações nesse período foi importante porque contribuiu para aumentar o nível das reservas internacionais em um período de fragilidade das contas externas do país. A segunda foi marcada pelo início do processo de aumento dos preços internacionais do petróleo a partir do fim de 1999. Já a terceira fase é marcada pela continuidade 
do processo de elevação do preço do petróleo nos mercados internacionais e pelo início de reformas econômicas realizadas principalmente ao longo do primeiro mandato de Vladimir Putin, que melhoraram consideravelmente os indicadores macroeconômicos da Rússia (LETICHE, 2007).

O início de ciclo da expansão da economia da Rússia nesse período é resultado da interação entre dinâmicas domésticas e externas.

Primeiro, a recessão econômica da Rússia na década de 1990 reduziu consideravelmente a utilização dos fatores de produção do país devido à própria desorganização econômica no processo de transição para uma economia de mercado. A taxa de desemprego, por exemplo, saltou de 5.2\% em 1992 para $13.3 \%$ em 1998. Mesmo a produção de petróleo, que é o principal produto de exportação da Rússia, teve considerável redução na década de 1990. A produção diária de petróleo reduziu-se de 8.02 milhões de barris, em 1992, para 6.09 milhões, em 1998, quando os preços do produto atingiram os menores valores na década de 1990. Foi observada também uma queda na produção de gás natural, outro importante produto de exportação da Rússia. Nesse sentido, com o fim do período de turbulências macroeconômicas a partir do fim da década de 1990, a economia russa começou a ter um período de recuperação econômica à medida que houve uma redução da própria capacidade ociosa dos fatores de produção que estavam subutilizados na década de 1990. (VINHAS DE SOUZA, 2007).

Shleifer e; Treisman (2005) argumentam também que o desempenho da economia russa nesse período não pode ser estigmatizado em virtude apenas dos indicadores econômicos e sugere que a intensidade da recessão econômica foi menor do que o habitualmente aceito por três motivos: (1) os indicadores oficiais superestimaram o PIB da Rússia no início da década de 1990 no período de transição para uma economia de mercado, devido em grande medida à contabilização de gastos militares, projetos ainda em desenvolvimento e outros produtos que não tinham mais demanda com a transição da Rússia para uma economia de mercado, (2) houve um crescimento acelerado da economia informal na década de 1990 que não foi captada pelos indicadores oficiais, o que na prática sugere que a recessão econômica foi menos intensa e (3) outros indicadores sugerem que os níveis de consumo no agregado da população não tiveram uma redução proporcional à redução do PIB per capita russo.

Outro fator fundamental no processo de recuperação da economia da Rússia está ligado à evolução dos preços e da demanda das commodities energéticas. Os preços do petróleo, que haviam recuado para valores próximos de US $\$ 12$ 
dólares o barril no fim de 1998, começaram a subir gradualmente a partir do fim de 1999. A média anual do preço do barril nos mercados internacionais saltou de aproximadamente US\$13 dólares, em 1998, para valores ao redor de US\$100 no decorrer da década de 2000. Os preços do gás natural registraram também forte elevação nos mercados internacionais. A média de preço das exportações russas de gás natural por metro cúbico elevou-se de US\$ 85, em 2000, para US $\$ 109$, em 2004, e atingiu seu maior valor em 2008, quando foram comercializadas no exterior a um preço médio de US\$353 por metro cúbico.

A evolução dos preços e da demanda internacional por commodities energéticas é uma variável central para o desempenho econômico da Rússia em virtude da elevada importância que o setor de petróleo e gás tem para a economia russa. Após o descobrimento de novas reservas de petróleo e gás natural no oeste da Sibéria, na década de 1970, a economia russa passou a ser mais dependente da exploração de commodities energéticas. Cálculos de Kuboniwa (2015) apontam que, entre 2005 e 2013, por exemplo, o valor adicionado do setor de petróleo e gás foi em média de aproximadamente $20 \%$ do PIB da Rússia. Esses valores não decorrem apenas da exploração stricto sensu do setor de petróleo e gás, mas também dos efeitos indiretos que essas atividades geram sobre o restante da economia da Rússia.

A importância do setor de petróleo e gás natural para a economia russa pode ser observada também sob a ótica da geração de rents ${ }^{6}$. Com a elevação dos preços e da demanda internacional, houve um significativo aumento dos rents, que elevaram naturalmente a renda da Rússia na década de 2000. Nas palavras de Gaddy e; Ickes (2015, p. 13): "Entre 1999 e 2013, os rents totais cresceram em aproximadamente US $\$ 4.2$ trilhões. Desse total, em torno de US\$ 3.2 trilhões decorreu do aumento dos preços do petróleo e do gás e o restante do aumento de 1 US\$ trilhão da produção."7

6 Gaddy e; Ickes (2013a) definem rent como a diferença entre as receitas obtidas com a venda de petróleo e os custos de produção do petróleo. Assim, rent é igual aos lucros realizados com a produção de petróleo. Nas palavras dos autores (2013a, p. 311): "Rents pode ser definido como a diferença de renda recebida das vendas de petróleo menos o custo de produção do mesmo”.

7 "Between 1999 and 2013, total rent grew by about USD 4.2 trillion. Of that, 3.2 trillion was due to the increase in the oil and gas prices, and 1.0 trillion to the increase in the quantity of oil and gas produced”. 
Figura 2. Evolução das exportações totais da Rússia em US\$ bilhões (coluna da esquerda) e do percentual das exportações de combustíveis em relação ao total (linha vermelha e coluna da direita)

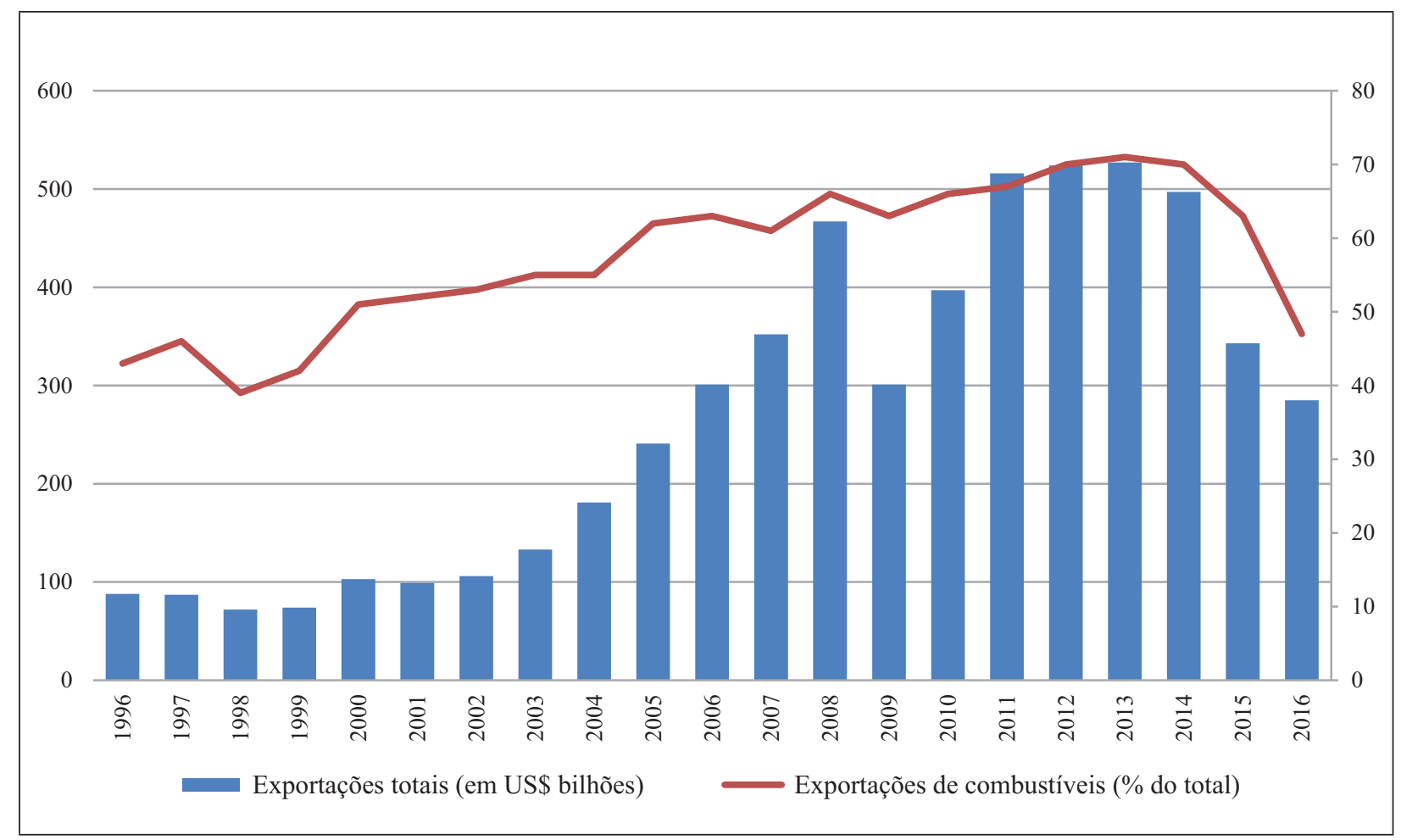

Fonte: Banco Mundial, 2018.

A elevada dependência da Rússia na exploração de commodities energéticas fica mais evidente com os dados da Figura 2, que demonstra a evolução das exportações totais do país e o percentual das exportações de combustíveis em relação ao total. As exportações de combustíveis começaram a ter maior crescimento proporcional em relação a outros bens e serviços a partir de 2000,quando atingiram $50 \%$ das exportações totais da Rússia. Essa proporção cresceu ao longo da década de 2000 e as exportações de combustíveis atingiram um total de $70.2 \%$ das exportações totais da Rússia em $2013^{8}$. Esses dados apenas confirmam a importância do setor de petróleo e gás e a baixa capacidade de diversificação da pauta de exportação da Rússia.

8 Além da produção de petróleo e gás natural, a Rússia possui em sua pauta de exportações outros produtos primários, como ferro, carvão e minerais. Esses produtos representam aproximadamente 8-9\% da pauta de exportação russa. Quando são adicionados esses bens à participação de commodities agrícolas, minerais e combustíveis nas exportações totais da Rússia, chega-se a uma média próxima de 70-75\% do total, o que reforça o caráter de baixa diversificação da estrutura produtiva russa (CONNOLLY, 2017). 
Figura 3. Evolução do preço internacional do petróleo (coluna da direita) e receitas do governo russo em bilhões de rublos (coluna da esquerda)

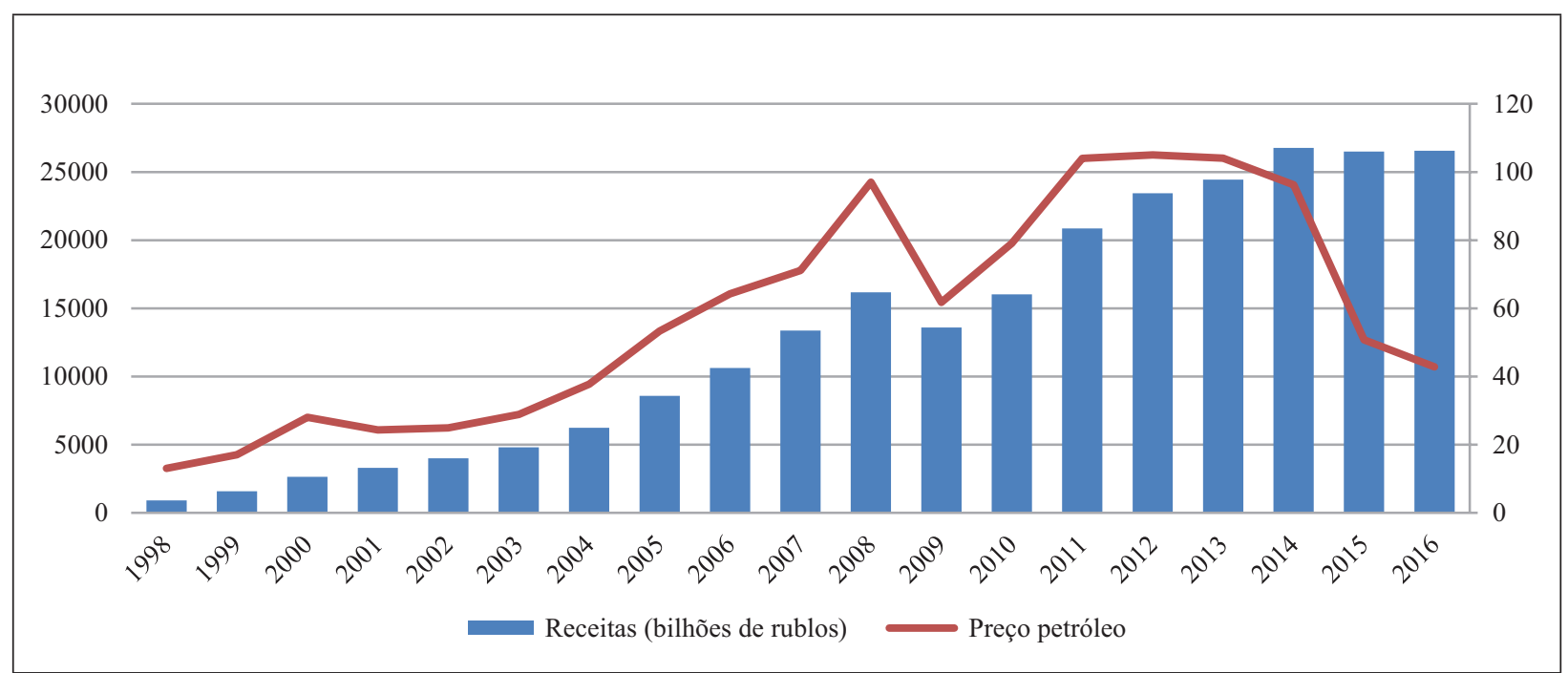

Fonte: FMI, 2018b. Para calcular o preço médio anual do petróleo utilizamos a média mensal em cada ano.

Na Figura 3, é possível observar o aumento significativo do preço do petróleo nos mercados internacionais a partir do início da década de 2000. Sabitova e; Shavaleyeva (2015) argumentam que a evolução do preço do petróleo e do gás natural teve três efeitos positivos para a economia da Rússia.

Primeiro, a elevação dos preços e da demanda internacional por commodities energéticas teve um impacto direto sobre o setor público da Rússia. Como é possível observar na Figura 3, existe uma relação direta entre a evolução dos preços internacionais do petróleo e a elevação das receitas tributárias do governo russo. À medida que houve um significativo aumento das receitas tributárias, os déficits fiscais foram revertidos em crescentes superávits fiscais ao longo da década de 2000.

A situação fiscal da Rússia teve sensível melhora também devido à realização de uma reforma tributária que aumentou consideravelmente a tributação sobre os ganhos econômicos oriundos da produção e exportação de petróleo, gás e derivados. Os impostos corporativos sobre os lucros das empresas petrolíferas cresceram de uma média de 10-15\%, em 1999, para um montante próximo de 30-35\%, em 2005. Como resultado, as receitas tributárias oriundas da produção de petróleo e gás saltaram de aproximadamente 1 trilhão de rublos, em 2004, para 4.3 trilhões de rublos, em 2008. Tal crescimento da arrecadação foi canalizado principalmente para impostos controlados pelo governo federal da Rússia. Em 2004, $30 \%$ das receitas federais do governo russo eram provenientes de impostos e taxas sobre o setor de petróleo e gás. Já em 2008, esse percentual aumentou para $47 \%$. 
Como resultado, as receitas do governo federal, entre 2004 e 2008, quase que triplicaram - de 3.4 trilhões de rublos em 2004 para 9.2 trilhões em 2008.

Outro instrumento importante que contribuiu para a estabilização macroeconômica a e melhora da situação fiscal da Rússia nesse período decorreu da criação do Russian Oil Stabilization Fund (OFS). O propósito do fundo era: a) reduzir a volatilidade das receitas tributárias em virtude da variação dos preços do petróleo nos mercados internacionais e b) ser utilizado para a realização de operações de esterilização ${ }^{9}$ no mercado financeiro da Rússia. Na prática, quando os preços do petróleo estivessem acima de certo patamar, estabelecido pelo governo russo, haveria a canalização das divisas internacionais para o OFS. Em contraposição, quando os preços ficassem abaixo do valor de referência mínimo, o governo russo iria se financiar dos montantes alocados no OFS. A criação do OFS foi importante porque propiciou ao governo russo aumentar a previsibilidade das receitas tributárias oriundas da taxação do setor de petróleo, em virtude da volatilidade dos preços das commodities energéticas nos mercados internacionais. (ASTROV, 2007).

A sensível melhora da situação fiscal do governo russo foi fundamental para a estabilização econômica na década de 2000, após intensas instabilidades macroeconômicas observadas ao longo da primeira década após o fim da Guerra Fria. A melhora da situação fiscal propiciou uma significativa redução da dívida pública, que havia alcançado um montante próximo de $92 \%$ do PIB da Rússia no fim da década de 1999. Esse montante reduziu-se progressivamente ao longo da década de 2000 e,em 2008, a dívida pública russa já era de apenas $7.4 \%$ do PIB - valor esse bem inferior à média observada em outras economias emergentes.

Em segundo lugar, a expansão das receitas fiscais permitiu ao governo russo ampliar o gasto público a partir do início dos anos 2000. O crescimento dos gastos públicos traduziu-se em melhoria dos serviços públicos e aumento da demanda doméstica. A elevação dos gastos públicos propiciou também um aumento das taxas de investimento realizado principalmente pelo governo central da Rússia. Ou seja, a elevação das receitas oriundas da exportação de gás e petróleo teve reflexos indiretos em outros setores da economia russa à medida que ocorreu uma ampliação da renda doméstica. Nas palavras de Aleksashenko (2012, p. 45):

9 Esterilização é um termo utilizado para designar as operações realizadas por um banco central nacional para controlar a liquidez e os meios de pagamento em uma economia nacional. As operações de esterilização podem ser realizadas por meio da compra e venda de títulos públicos. São utilizadas normalmente para enxugar o excesso de liquidez em virtude da entrada excessiva de divisas internacionais por meio das exportações ou mesmo da entrada de investimentos internacionais. 
"Além do aumento das receitas tributárias, a renda oriunda do setor de petróleo e gás resultou em efeitos indiretos sobre o crescimento econômico. Assim, mesmo que não mais do que 1.5 - 2\% (de um crescimento médio anual de 7 por cento entre 2000 e 2008) do crescimento do PIB possa ser atribuído diretamente ao setor de óleo e gás, outros $3-4 \%$ da expansão econômica derivam de efeitos indiretos da entrada de divisas internacionais que resultaram em uma rápida expansão da demanda doméstica. externos que resultaram em uma rápida expansão da demanda doméstica10”.

Por último, as crescentes receitas oriundas da exportação de commodities energéticas reduziram consideravelmente a vulnerabilidade externa da economia frente à ocorrência de choques externos, esse último um dos principais fatores para a eclosão da crise financeira de 1998. As exportações russas, que atingiram o montante de US\$ 74 bilhões em 1999, cresceram progressivamente a partir da elevação dos preços e da demanda internacional por commodities energéticas. Entre 1999 e 2008, as exportações totais se multiplicaram em aproximadamente seis vezes. Como resultado desse fenômeno, as reservas internacionais do país subiram de pouco mais de US\$ 17 bilhões, em 1999, para mais de US\$ 426 bilhões, em 2008. Não por acaso, o gigantesco crescimento das reservas internacionais foi fundamental para a criação de um colchão de liquidez para a redução da vulnerabilidade externa da Rússia frente a choques externos ${ }^{11}$.

Em suma, o início do boom das commodities internacionais ao longo da década de 2000 gerou efeitos diretos sobre a economia da Rússia. De todo modo, a significativa melhora da performance da economia da Rússia a partir do fim da década de 1990 não pode ser também descontextualizada dos aspectos domésticos. A realização de uma reforma tributária que canalizou o aumento dos rents para o setor público e a criação de um fundo financeiro foram instrumentos importantes para equilibrar as contas públicas da Rússia, que era uma das principais fragilidades macroeconômicas do país na década de 1990. À medida

10 "Besides their direct influence on budgetary incomes, oil proceeds have exercised a substantial indirect effect on economic growth. Thus, even if no more than $1.5-2$ percent (out of 7 per cent average annual growth in 2000-2008) of overall expansion could be attributed directly to growth in the oil and gas industry, another 3-4 percentage point derive from its indirect effects, in the form of an influx of external finance resulting in a rapid expansion of internal demand".

11 Importante ressaltar que esse fenômeno não ficou circunscrito à Rússia. Após as crises financeiras da década de 1990, importantes economias emergentes passaram a adotar estratégias que tinham como objetivo elevar os níveis de reservas internacionais para reduzir a vulnerabilidade externa frente a choques dentro da economia mundial. Essas estratégias eram baseadas principalmente na desvalorização artificial do câmbio e em políticas voltadas à promoção de exportações. Sobre o tema ver Wolf (2008). 
que ocorreu uma estabilização dos indicadores macroeconômicos, ocorreu também uma elevação dos fatores de produção, subutilizados na década de 1990. Assim, ocorreu progressivamente a eliminação dos desequilíbrios entre oferta e demanda presentes na década de 1990, quando a Rússia se tornou uma economia de mercado (HANSON, 2007).

\section{A economia da Rússia no pós-crise global de 2008}

O início da crise no setor imobiliário dos Estados Unidos, e que posteriormente tornou-se global, teve impactos diretos sobre a economia mundial e a própria Rússia. A dimensão da magnitude da crise global de 2008 é descrita nas seguintes palavras de Roubinie; Mihn (2010, p. 150) “No quarto trimestre de 2008 e no primeiro trimestre de 2009 a economia global se contraiu numa porcentagem que só teve paralelo, em tamanho e profundidade, com o colapso de 1929 a 1931, que deu início à grande depressão”.

Tabela 1. Crescimento econômico em preços constantes (\% do PIB) em economias e grupos de países selecionados

\begin{tabular}{lccccccccccc}
\hline País & Média (1999-2008) & 2009 & 2010 & 2011 & 2012 & 2013 & 2014 & 2015 & 2016 & 2017 \\
\hline Rússia & 6.8 & -7.8 & 4.5 & 4 & 3.5 & 1.2 & 0.7 & -2.8 & -0.2 & 1.7 \\
Mundo & 4.1 & -0.1 & 5.3 & 4.2 & 3.5 & 3.4 & 3.5 & 3.3 & 3.2 & 3.6 \\
Países Desenvolvidos & 2.4 & -3.4 & 3 & 1.7 & 1.1 & 1.3 & 2 & 2.2 & 1.6 & 2.1 \\
Países Emergentes e Pobres & 6.1 & 2.8 & 7.4 & 6.4 & 5.3 & 5.1 & 4.6 & 4.2 & 4.3 & 4.6 \\
\hline
\end{tabular}

Fonte: FMI, 2018a.

A recessão da economia global só não foi mais profunda devido à rápida recuperação das economias emergentes e pobres - liderados principalmente por China e Índia - que, apesar da desaceleração econômica, registraram um crescimento médio próximo de $2.8 \%$ em 2009. A Tabela 1 demonstra o quadro de deterioração da economia global a partir da crise global de 2008. Essa conjuntura da economia global teve reflexos diretos sobre a Rússia a partir da eclosão da crise global de 2008. Em 2009, por exemplo, a economia russa teve o pior desempenho desde o fim da década de 1990, ao registrar uma retração de $7.8 \%$, que foi superior inclusive à registrada nos Estados Unidos. 
Nos anos posteriores à eclosão da crise global de 2008, ocorreu uma progressiva redução das taxas de crescimento do PIB da Rússia, que culminou na recessão econômica no biênio 2015/2016. Uma explicação natural para essa nova conjuntura da economia da Rússia está ligada ao fim do superciclo das commodities internacionais e à recessão econômica na Europa, que reduziu ainda mais a demanda por produtos russos. De fato, a partir de 2014, houve forte desaceleração dos preços das commodities energéticas nos mercados internacionais. Os preços do petróleo começaram a declinar no segundo semestre de 2014 e atingiram, em 2015, os menores valores desde o início da década de 2000. Em janeiro de 2016, por exemplo, o preço do barril era negociado a valores próximos de 30 US $\$ 12$.

Apesar da forte redução dos preços das commodities energéticas, a economia da Rússia já havia perdido dinamismo a partir do início da década de 2010, quando o crescimento do PIB registrou significativa desaceleração em comparação ao período pré-crise global de 2008. Essa constatação sugere que o modelo de crescimento econômico começou a exaurir-se no período pós-crise global de 2008 e foi acentuado a partir da queda dos preços das commodities energéticas nos mercados internacionais. Ou seja, a perda de dinamismo da economia da Rússia está ligada a outros fatores que vão além do fim do superciclo das commodities internacionais.

Um segundo fator da conjuntura internacional, que vai além de questões econômicas e que está influenciando a economia da Rússia, decorre das rivalidades geopolíticas com o mundo ocidental. O acirramento das disputas da Rússia com o mundo ocidental atingiu o ápice com a eclosão da crise da Crimeia no início de 2014, que culminou na aplicação de sanções econômicas contra a Rússia por parte do mundo ocidental desenvolvido. Essas sanções podem ser classificadas em três níveis: sanções diplomáticas, contra pessoas e organizações e sanções econômicas ${ }^{13}$.

No tocante aos aspectos econômicos, as sanções ocidentais contra a Rússia podem ser classificadas em dois tipos: (1) financeiras - que restringem a realização de operações de empréstimos e transações financeiras realizadas entre bancos e instituições financeiras ocidentais com empresas financeiras e não-financeiras

12 A redução dos preços e da demanda do petróleo nos mercados internacionais não é somente um fenômeno ligado à desaceleração da economia global. O surgimento e expansão da indústria de xisto nos Estados Unidos, a maior oferta proveniente de fontes alternativas de energia (eólica, solar) e a política da Arábia Saudita de não reduzir a produção de petróleo tiveram reflexos diretos sobre os preços internacionais do petróleo em virtude do aumento da oferta. Sobre o assunto ver Viola e; Basso (2015).

13 Para ver um resumo e detalhes de cada sanção aplicada contra a Rússia, ver European Parliament (2015). 
russas e (2) embargo para a venda e comercialização de tecnologias desenvolvidas por empresas ocidentais para a Rússia. Além disso, as sanções implicaram a existência de restrições para atuação em conjunto de empresas ocidentais e russas no desenvolvimento de projetos voltados para o setor de petróleo e gás.

A aplicação das sanções financeiras reduziu consideravelmente os níveis de interdependência financeira entre bancos e empresas da Rússia com instituições bancárias do mundo ocidental. Em 2014 e 2015, as empresas e instituições financeiras da Rússia foram obrigadas a liquidar débitos com bancos ocidentais que totalizaram valores próximos a US\$ 180 bilhões. A liquidação desses débitos foi o principal fator que contribuiu para a súbita saída de capitais internacionais e a desvalorização do rublo russo nesse período (EUROPEAN PARLIAMENT, 2015).

Figura 4. Evolução da entrada de IED (US\$ bilhões) na Rússia

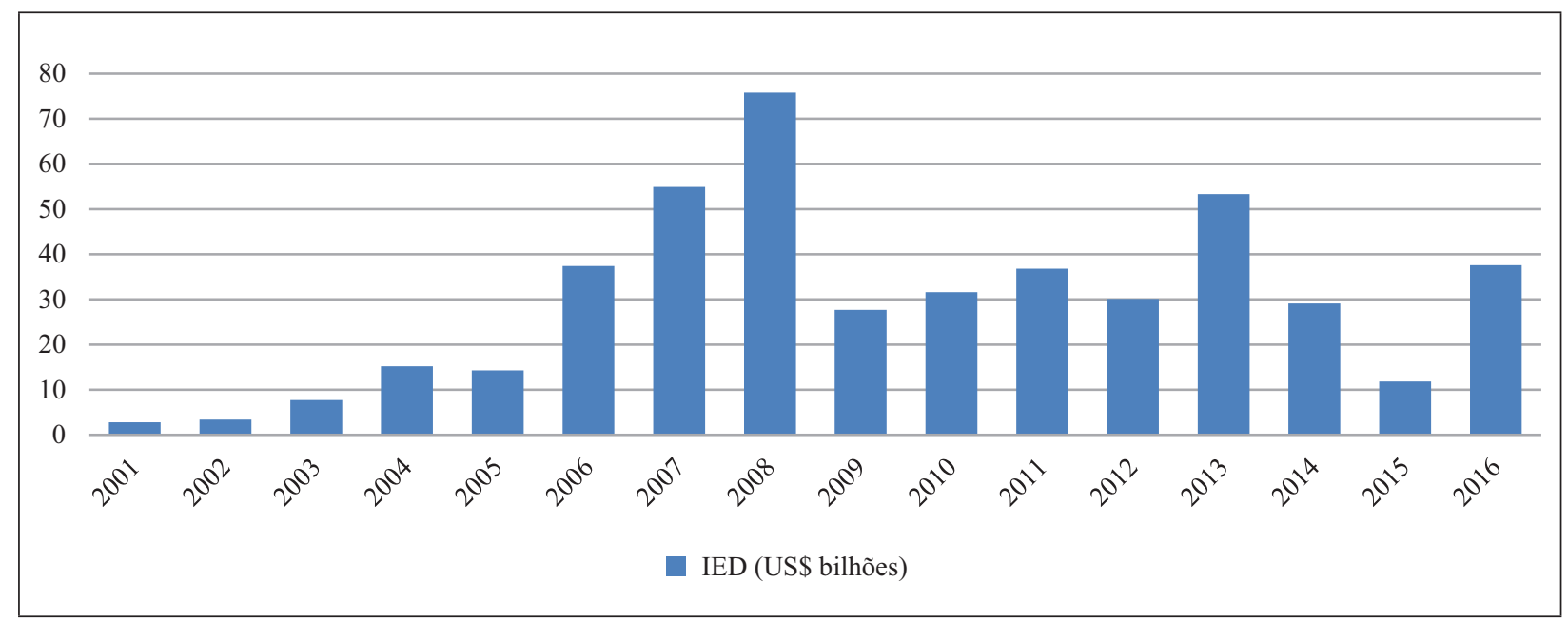

Fonte: Unctad, 2018.

O clima de incerteza gerado pelas sanções econômicas e pela intensificação das rivalidades geopolíticas reduziu também os níveis de investimentos externos de longo prazo realizados principalmente por empresas ocidentais na Rússia. A Figura 4 demonstra que a entrada de Investimento Estrangeiro Direto (IED) na Rússia atingiu seus menores níveis em 2014 e 2015. Mesmo com o relativo crescimento registrado em 2016, as sanções econômicas tiveram forte impacto sobre a realização de investimentos internacionais na Rússia, no curto prazo, na média trienal de 2014-2016.

A adoção de sanções econômicas tem reflexos no curto prazo já que impossibilita que empresas russas realizem operações de empréstimos com bancos e instituições financeiras, principalmente com os países da Europa Ocidental. Além disso, as proibições de transferência de bens que contém tecnologia militar 
ocidental afetam diretamente a cadeia de produção de armamentos da Rússia, que é outro importante setor dessa economia. Mas esses efeitos tendem a ter reflexos para a economia russa no médio prazo, especialmente no tocante à prospecção de novos campos de petróleo (CONNOLLY; SENDSTAD, 2017). Como observa Connolly et al. (2015):

"A recuperação da produção após o fim da União Soviética deveu-se em grande parte ao aumento da produção nos campos convencionais e ao papel desempenhado pelas joint-ventures com as empresas Ocidentais. Mas o declínio da produção nos campos convencionais no oeste da Sibéria seria compensado pelo aumento da produção de petróleo no Ártico. Devido à perda de acesso ao capital e tecnologia norte-americana esse esperado aumento da produção ficou comprometido em um futuro próximo. Além disso, a imposição de um prazo máximo de noventa dias para o pagamento de empréstimos contraídos com instituições financeiras da União Europeia resulta em uma redução de recursos financeiros para a realização de investimentos no setor de petróleo ${ }^{14 "}$.

De todo modo, mesmo que a deterioração da conjuntura internacional tenha gerado reflexos econômicos negativos, a relativa estagnação da economia da Rússia, a partir do início da década de 2010, decorre principalmente de aspectos domésticos. Essa constatação tem suas bases no próprio desempenho da economia da Rússia que, antes do fim do superciclo das commodities internacionais e do próprio acirramento das disputas geopolíticas com o mundo ocidental, já dava sinais de forte desaceleração econômica. Entre 2009 e 2013, por exemplo, a taxa de crescimento do PIB da Rússia foi de apenas $1.2 \%$ ao ano.

\section{As dinâmicas estruturais da estagnação da economia da Rússia}

O quadro de relativa estagnação da economia da Rússia a partir da década de 2010 reforça a percepção da existência de fragilidades domésticas de caráter estrutural. Ou seja, apesar de uma deterioração da conjuntura internacional, devido

14 "The recovery of production during the post-Soviet period was largely due to enhanced output at conventional fields and the key role played by joint ventures (JVs) with Western companies. But the expected decline in oil production from onshore conventional fields in Western Siberia was to be compensated for by tight oil production and Arctic exploration. Owing to the loss of access to US technology and capital, such plans are now jeopardized. Moreover, the 90-day maturity period for new debt issued by Russian energy companies stipulated by the EU sanctions poses limits on various types of potential financing." 
à própria desaceleração da economia global no contexto pós-crise de 2008 , do fim do superciclo das commodities internacionais e dos reflexos econômicos em virtude das sanções econômicas contra a Rússia, a forte desaceleração econômica a partir do início da década de 2010 está relacionada a questões domésticas.

Tabela 2. Evolução da produtividade por trabalhador (em US\$ constantes de PPC de 2011) em economias e grupos de países selecionados

\begin{tabular}{lcccc}
\hline País & 1991 & 2000 & 2008 & 2016 \\
\hline Rússia & 43.758 & 31.746 & 47.309 & 49.076 \\
Países de renda média alta & 12.814 & 15.204 & 23.044 & 31.835 \\
Países de alta renda & 65.467 & 78.685 & 86.485 & 91.447 \\
Mundo & 21.232 & 24.278 & 29.515 & 33.725 \\
\hline
\end{tabular}

Fonte: Organização Internacional do Trabalho, 2018.

O quadro de relativa estagnação da economia russa pode ser observado por meio da produtividade do trabalho. Como é possível observar na Tabela 2, a produtividade do trabalhador russo passou por alterações a partir do início da década de 1990. Em um primeiro momento, houve uma significativa queda da produtividade do trabalhador russo em comparação aos países de alta renda na década de 1990. Esse fenômeno foi revertido a partir do início da década de 2000, em virtude das elevadas taxas de crescimento do PIB no período de maior ascensão econômica da Rússia. Contudo, a partir de 2008, o processo de convergência da produtividade do trabalhador russo em relação aos países de alta renda chegou ao fim. Entre 2008 e 2016, a produtividade média de um trabalhador da Rússia em comparação à média dos países de alta renda reduziu-se de $54 \%$ para $53 \%$.

Esse quadro apenas confirma a percepção de que, mesmo com o quadro de relativa estagnação econômica das economias desenvolvidas após a eclosão da crise global de 2008, a Rússia não deu continuidade ao processo de convergência ou catch up de renda em virtude de fragilidades domésticas. Essas fragilidades são resultado de uma economia que possui indicadores de produtividade e competitividade abaixo da média observada nos países de alta renda e também de níveis de investimentos produtivos insuficientes para elevar os estoques de capitais e promover uma maior diversificação produtiva.

No período de maior bonança da economia global e do superciclo das commodities internacionais, os recursos oriundos da exportação de hidrocarbonetos 
não foram convertidos em um aumento sistêmico da competitividade e da produtividade dos demais setores da economia da Rússia. Gaddy e; Ickes (2015) apontam que esse processo decorre da administração dos rents (rent management) a partir da era Putin, que priorizou a transferência dos recursos para atividades de menor competitividade e produtividade. Os preços domésticos, por exemplo, reduzem a lucratividade das empresas em virtude de subsídios que variam entre $31 \%$ a $46 \%$ em relação aos preços internacionais. Ademais, o governo russo subsidia o gás natural que é exportado para os países da Comunidade dos Estados Independentes (CEI). Persistem também outros canais indiretos que reduzem a rentabilidade das empresas em virtude do pagamento de propinas a agentes públicos e custos excessivos ${ }^{15}$.

Para Gaddy e; Ickes (2013a), a dinâmica pelo qual são distribuídos os rents oriundos do setor de petróleo e gás cria um dualismo nas atividades produtivas da Rússia. O primeiro é representado pelo setor de produção e comercialização de hidrocarbonetos, sendo responsável pelo aumento da renda nacional ao longo da década de 2000. Já o segundo setor é representado por atividades produtivas de menor produtividade e que são beneficiadas pela transferência dos rents do setor de petróleo e gás natural. Essa dinâmica é um dos principais fatores que explicam porque o aumento dos rents durante o superciclo das commodities internacionais não ocasionou um processo de modernização e diversificação produtiva da economia da Rússia. (GURIEV; TSYVINSKI, 2010). Nas palavras de Kudrin e; Gurvich (2015):

As enormes receitas excedentes que o país recebeu devido às condições favoráveis nos mercados de produtos primários resultaram em um crescimento considerável da produção, um aumento recorde da renda das famílias (juntamente com um aumento da renda em todos os setores, incluindo o setor público, pensões, etc), e garantiram a estabilidade macroeconômica. De todo modo, não se pode dizer que o aumento desses recursos tenham resultado em um processo de modernização econômica (na forma de investimentos governamentais, despesas para criar instituições de desenvolvimento, vários subsídios, etc.)

15 Os custos excessivos decorrem principalmente de ineficiências produtivas na exploração de petróleo e gás natural. O transporte do petróleo, por exemplo, é realizado principalmente por meio de ferrovias, que é um meio de transporte significativamente mais dispendioso em comparação à utilização de oleodutos. A preferência pela utilização de ferrovias está ligada a interesses das autoridades políticas de Moscou. A Uralvagonzavod é a principal empresa produtora de vagões de trem e também fornece tanques para o exército da Rússia e se beneficia diretamente da utilização de ferrovias para o transporte de petróleo. 
que produziram resultados tangíveis, já que a competitividade internacional da Rússia não teve melhora significativa16.

Connolly (2015) argumenta que a formulação composta por dois setores é excessivamente reducionista e deve ser contemplada pela existência de um terceiro setor que é formado por empresas relativamente pequenas e que atuam principalmente no setor de serviços. Esse setor não depende da transferência de recursos do setor estatal para se manter competitivo nos mercados nacionais e internacionais. Embora esse setor não necessite de subsídios estatais, a performance da economia russa afeta diretamente sua produtividade em virtude da necessidade do estado russo prover, principalmente, infraestrutura, saúde e educação pública. Nesse sentido, a exaustão financeira do estado russo afeta diretamente o desempenho econômico desse setor que gera aproximadamente $20 \%$ dos empregos e da renda na Rússia ${ }^{17}$.

\section{Tabela 3. Participação das exportações da Rússia nos mercados mundiais (\% do total global)}

\begin{tabular}{lccc}
\hline & 2001 & 2008 & 2013 \\
\hline Non-fuel & 0.88 & 1.21 & 1.02 \\
Máquinas e equipamentos & 0.28 & 0.30 & 0.33 \\
\% da Rússia nos mercados globais & 0.94 & 2.67 & 2.81 \\
\hline
\end{tabular}

Fonte: Kudrin; Gurvich, (2015).

A incapacidade da Rússia em reduzir a dependência das exportações de petróleo e elevar os níveis de produtividade do país em setores não ligados à produção de commodities energéticas pode ser observada mais precisamente na Tabela 3. A participação das exportações russas ganhou espaço nos mercados internacionais ao saltar de $0.94 \%$ das exportações mundiais, em 2001, para $2.81 \%$, em 2013. Contudo, o crescimento do market sharing da Rússia nos mercados globais decorreu, em grande medida, do aumento das exportações de commodities

16 "The huge surplus revenues the country received due to favourable conditions in the primary material markets considerably accelerated production growth, ensured a record-breaking increase in household income (together with wages in all branches, including the public sectors, pensions, etc), and enhanced macroeconomic stability. At the time, one cannot say that the substantial resources allocated for economic modernization (in the form of government investments, expenses for creating developmental institutions, various subsidies, etc.) yielded any tangible results, as Russia's international competitiveness has not improved."

17 Esse setor é composto de empresas que possuem competitividade nos mercados internacionais. A Rússia possui, por exemplo, aproximadamente 2.300 empresas do setor de softwares. Desse total, em torno de 1500 exportam produtos de alto valor agregado relacionados a serviços e produtos na indústria de softwares. Além do setor da informática, nesse grupo encontram-se empresas de transporte e serviços financeiros e gerais. 
energéticas. As exportações russas oriundas de setores não ligados ao setor de hidrocarbonetos ficaram praticamente estagnadas nesse período. Entre 2001 e 2013, por exemplo, as exportações russas de máquinas e equipamentos tiveram um crescimento substancialmente menor em comparação ao setor energético (KUDRIN; GURVICH, 2015).

Um segundo fator que afeta a eficiência produtiva da economia da Rússia está relacionado ao aprofundamento das relações de crony capitalism. Os anos 1990 foram marcados essencialmente pelo progressivo processo de desmantelamento do Estado russo por meio da realização de um amplo processo de privatização das empresas estatais. A partir do segundo mandato de Vladimir Putin (2004-2008), esse processo começou a ser revertido por meio da maior centralização das receitas oriundas de impostos e taxas, no âmbito do governo federal russo, e pelo crescimento da participação do Estado como acionista, principalmente, das empresas ligadas ao setor energético (ASLUND, 2014).

Empresas do setor financeiro, energia, transportes e mídia passaram a ser mais controladas pelo governo, seja por meio de regulação ou da participação acionário do governo russo. Em 2005, por exemplo, 70\% dos ativos do setor financeiro eram controlados por agentes privados enquanto que, em 2015, esse percentual já havia caído pela metade. Em meados de 2015, aproximadamente $55 \%$ da economia russa estava sob controle direto do Estado. Essas políticas incluem também o apoio a grandes empresas públicas e privadas nacionais por meio da existência de subsídios e financiamentos estatais. Além disso, o Estado russo estabeleceu uma política de "campeões nacionais", com o intuito de dar suporte a empresas nacionais. Em resumo, as reformas conduzidas no período Putin culminaram com a transição do crony capitalism dos anos 1990, representado pelo crescente poder dos oligarcas, para um mix, com o fortalecimento também de um capitalismo de Estado. Nas palavras de Djankov (2015),

"Essa mudança resultou no fim do capitalismo de compadrio e no início do
capitalismo de estado, onde o Estado ou possuía os principais ativos produtivos
ou eram mantidos por amigos pessoais do presidente, que colocariam suas
empresas à disposição do Estado em troca por meio de contratos públicos,
acesso a crédito fácil através de bancos estatais e a proteção de sua riqueza. ${ }^{18 "}$

18 "This shift presaged the end of crony capitalism and the start of state capitalism, where the state either owned the main productive assets outright or they were held by personal friends of the president, who would put their companies at the disposal of the state in exchange of government contracts, access to easy credit through state-owned banks, and the protection of their wealth". 
A disfuncionalidade desse modelo pode ser percebida por meio da origem e crescimento da classe de bilionários do país. O aumento do número de bilionários em um país normalmente é resultado de dois fenômenos: (1) surgimento de novos empreendedores que atuam na produção ou serviços de alta tecnologia. Nesse caso, o acúmulo de fortunas decorre da exploração de novos mercados e tecnologias de alto valor agregado19; e (2) a classe de bilionários é composta essencialmente por empresários que atuam em setores tradicionais como construção, mercado imobiliário, mineração, hidrocarbonetos e outras commodities (SHARMA, 2016).

Sharma (2016) classifica o primeiro tipo como os "bons bilionários" e o segundo tipo como os "maus milionários". Essa classificação decorre do fato que a riqueza dos bons bilionários tem origem essencialmente na produção de bens e serviços em setores de alto valor agregado, que se reflete em inovação e competitividade sistêmica da economia de um país. Não por acaso, por exemplo, os bons bilionários que produzem bens e serviços com maior nível de inovação e também no limite da fronteira tecnológica concentram-se principalmente nas economias desenvolvidas e ricas. Ao contrário, nos setores constituídos pelos maus bilionários, o nível de inovação e competição tende a ser menor e o acúmulo de fortunas decorre em grande medida da associação direta ou indireta com o setor público e derivam de atividades predominantemente baseadas no rent-seeking. Esse é precisamente o caso da Rússia.

A existência de um elevado percentual da renda nacional controlada pelos “maus bilionários" é um sinal de uma economia com menor propensão à inovação e, por seguinte, modernização. Na prática, o processo de modernização produtiva de uma economia decorre, em grande medida, do processo de criação destrutiva ${ }^{20} \mathrm{e}$ do surgimento de novas tecnologias disruptivas ${ }^{21}$. Em economias onde predominam os maus bilionários, tal fenômeno é bloqueado pelos grupos econômicos que se

19 Esses novos bilionários, em muitos casos, são fundadores de empresas que tiveram crescimento gigantesco em poucos anos e incluem, por exemplo, os fundadores de empresas como Facebook, Amazon, Google e outras ligadas principalmente ao setor de alta tecnologia.

20 O termo destruição criativa foi cunhado pelo economista austríaco, Joseph Schumpeter, para descrever o processo de desenvolvimento econômico em uma economia capitalista. A substituição de processos produtivos por novas técnicas produtivas mais eficientes é a base do processo de inovação de economias de mercado. Sobre o termo e sua aplicação no caso russo, ver Guriev e; Tsyvinski (2010).

21 O termo tecnologia disruptiva é utilizado para designar o surgimento de novos padrões tecnológicos que implique em uma ruptura com os padrões de tecnologias vigentes. Esse é o caso principalmente das tecnologias ligadas à terceira e à quarta revoluções industriais. Sobre as características gerais da quarta revolução industrial, ver Schwab (2016). 
beneficiam do status quo, o que acaba reduzindo os níveis de competitividade sistêmica do próprio país Como ressalta Sharma (2016, p. 131): "É um mau sinal quando a classe bilionária de um país possui uma parcela excessiva da economia, se torna uma elite entrincheirada e inata, e produz sua riqueza principalmente de indústrias que dependem da regulamentação governamental. Uma economia saudável precisa de magnatas produtivos e não de magnatas corruptos ${ }^{22}$ ".

Além de questões relacionadas à eficiência econômica, a relativa estagnação da economia da Rússia está relacionada também à insuficiência de investimentos produtivos. Nas palavras de Aleksashenko (2012, p. 37): “Considera-se que, nas economias em desenvolvimento, o investimento deve representar $25 \%$ a $30 \%$ do PIB, na Rússia os níveis de investimento estão em um nível não maior do que 21-22\% ${ }^{23}$. Como é possível observar na Tabela 4 , a taxa média de investimento na Rússia, entre 2000 e 2015, ficou abaixo da média observada nas maiores economias emergentes - com exceção do Brasil - e também em um patamar inferior à observada na própria média global. Mesmo no período de maior crescimento do PIB, entre 2000 e 2008, a taxa média de investimento ficou ao redor de $20 \%$ do PIB.

Tabela 4. Taxa média anual de investimento em \% do PIB, entre 2000 e 2015, em economias emergentes selecionadas

\begin{tabular}{lc}
\hline & Média anual em \% do PIB (2000-2015) \\
\hline China & $42.6 \%$ \\
Índia & $35.3 \%$ \\
Indonésia & $30.1 \%$ \\
Turquia & $26.3 \%$ \\
México & $22.3 \%$ \\
Rússia & $20.5 \%$ \\
Brasil & $19.4 \%$ \\
Mundo & $24.3 \%$ \\
\hline
\end{tabular}

Fonte: FMI, 2018a.

Connoly (2013) observa que, no caso da Rússia, existe forte relação de causalidade entre o baixo nível de desenvolvimento dos mercados financeiros e

22 "It's a bad sign if the billionaire class owns a bloated share of the economy, becomes an entrenched and inbred elite, and produces its wealth mainly from politically connected industries. A healthy economy needs an evolving cast of productive tycoons, not a fixed cast of corrupt tycoons".

23 "It is considered that in developing economies investment should make up 25-30 per cent of GDP, yet Russia the level is no higher than 21-22 per cent". 
a realização de investimentos produtivos. Esse fenômeno é resultado da interação de quatro fatores: (1) o Estado controla e aloca a maior parte do crédito nacional, o que naturalmente reduz a disponibilidade da poupança para setores não contemplados pelas autoridades econômicas da Rússia, (2) o sistema privado bancário russo é composto majoritariamente por pequenos bancos. Os maiores bancos estão sob o controle estatal e direcionam seus empréstimos essencialmente para grandes empresas que possuem apoio político de Moscou, (3) o sistema financeiro russo é financiado basicamente por operações bancárias. As empresas que possuem ações negociadas nas bolsas de valores são predominantemente grandes companhias ligadas ao setor energético e os mercados para a comercialização de dívidas privadas têm pouca relevância e (4) a participação de bancos estrangeiros é limitada, o que reduz a oferta final de capitais para potenciais tomadores de empréstimo na Rússia.

O baixo nível de investimentos produtivos da Rússia está relacionado também a questões relativas aos direitos de propriedade. O relatório do World Economic Forum (2017)24 aponta que, nessas variáveis, a Rússia possui notas e posicionamento bem abaixo do esperado para uma economia de alta renda média que busca convergir seus níveis de renda para os níveis de países desenvolvidos. Alguns desses dados estão disponibilizados na Tabela 5.

\section{Tabela 5. Evolução das notas e posição da Rússia em tópicos específicos no relatório de competitividade do World Economic Forum (2016-2017)}

\begin{tabular}{lcc}
\hline & Nota (1-7) & Posição no Ranking Global \\
\hline Direitos de propriedade privada & 3.5 & $123^{\circ}$ \\
Independência do judiciário & 3.3 & $117^{\circ}$ \\
Proteção dos direitos dos acionistas minoritários & 3.5 & $116^{\circ}$ \\
\hline
\end{tabular}

Fonte: World Economic Forum (2017).

No ranking de competitividade global, a Rússia ocupa a $43^{\text {a }}$ posição geral. Todavia, nos quesitos tocantes a questões que envolvemos direitos de propriedade privada, independência do judiciário e proteção aos acionistas minoritários, a posição da Rússia é bem abaixo da média observada em comparação às economias de alta renda. A evolução desses quesitos é fundamental, principalmente para a

24 Mesmo que a construção desses índices envolva valores subjetivos e de difícil mensuração, a própria metodologia empregada é baseada na opinião dos próprios agentes econômicos, o que reforça a importância desses quesitos para melhorar o próprio ambiente de negócios no país. 
transição de países de renda média para economias desenvolvidas. No caso russo, existe forte nexo entre direitos de propriedade privada, proteção aos acionistas minoritários, independência do judiciário e a realização de investimentos produtivos. Esse fenômeno tem impactos negativos principalmente para a realização de investimentos de longo prazo e explicam a redução dos investimentos, por exemplo, na exploração de novas reservas de hidrocarbonetos que comprometem a produção futura no setor energético. Como observam Gaddy e; Ickes (2013, p. 574): "Quando há incerteza sobre os direitos de propriedade, a melhor decisão é esgotar os recursos no curto prazo e não desenvolver novos campos para o futuro" 25 .

\section{Considerações Finais}

Em certo sentido, não é exagero comparar literalmente o desempenho da economia da Rússia a partir do fim da Guerra Fria ao trajeto de uma montanha russa. Essa constatação deve-se à alta volatilidade dos indicadores de renda da Rússia a partir da transição do país para uma economia de mercado no início dos anos de 1990. A década de 1990, por exemplo, foi marcada por intensas instabilidades macroeconômicas e por uma profunda recessão econômica. Esse período acabou a partir do fim dos anos de1990, quando teve início um novo ciclo de expansão econômica que se prolongou até a eclosão da crise global de 2008. O período de recuperação da economia da Rússia não ocorre por acaso e está ligado principalmente ao início do superciclo das commodities internacionais e à realização de reformas domésticas que foram decisivas para colocar fim às instabilidades macroeconômicas que marcaram a década perdida de 1990.

Após a eclosão da crise global de 2008, a economia da Rússia entrou em uma nova fase marcada por uma relativa estagnação econômica. Mesmo com a recuperação dos preços das commodities energéticas, após o epicentro da crise global de 2008, a economia da Rússia já não mostrou o mesmo dinamismo em comparação aos anos de maior crescimento econômico. Entre 2010 e 2014, ocorreu um progressivo declínio da taxa de crescimento do PIB e o país entrou em recessão econômica a partir do biênio 2015/2016. Além da substancial queda dos preços das commodities energéticas, as rivalidades políticas da Rússia com o mundo ocidental entraram em uma nova fase a partir da eclosão da crise da Crimeia. A aplicação de sanções econômicas reduziu consideravelmente o acesso das

25 "When there is uncertainty over the future of one's property, the optimal decision is to deplete what you have, not to develop new fields for the future”. 
empresas russas aos mercados financeiros internacionais e também tem reflexos sobre o setor de petróleo e gás em virtude de restrições impostas pelos governos dos Estados Unidos e da Europa para transferência de tecnologia e a realização de empreendimentos em comum com empresas da Rússia.

Esse cenário apenas reforça a percepção de que os preços das commodities energéticas é uma variável fundamental para explicar o desempenho da economia da Rússia nas últimas décadas. De todo modo, o significativo crescimento da renda a partir do início do superciclo das commodities internacionais não resultou em ganhos estruturais de longo prazo no tocante a um maior processo de modernização e diversificação produtiva da economia da Rússia. Ao contrário disso, a dependência do setor de petróleo e gás, como principal indutor do crescimento econômico, elevou-se no decorrer da década de 2000. Essa dinâmica está relacionada diretamente a uma dualidade no sistema produtivo russo e à transferência dos rents do setor de petróleo e gás para outras atividades que possuem menores níveis de competitividade e produtividade.

A incapacidade de maior diversificação produtiva da Rússia reflete-se, por exemplo, na alta concentração de commodities energéticas na pauta de exportação do país. Além de questões relacionadas à baixa eficiência econômica, a economia russa registra também taxas de investimento inferiores aos países em desenvolvimento que passaram por períodos de aceleração econômica a partir do início do novo milênio. Essas deformidades e fragilidades e a transição incompleta da Rússia para uma economia de mercado mais competitiva é expressa nas seguintes palavras de Letiche (2007, p. 60):

Para alcançar o desenvolvimento econômico no longo prazo, a Rússia depende do estabelecimento de um ambiente de negócios satisfatório para a expansão do investimento privado. No entanto, no recente processo de transição, as reformas políticas e econômicas na Rússia enfrentam um trilema marcado pela existência de: um sistema econômico de quase-mercado, uma burocracia destrutiva e a persistência de uma corrupção sistêmica. Essas características resultam não apenas na redução da taxa de investimento nacional e estrangeiro, mas impedem também uma maior integração da Rússia com a própria economia mundial26.

26 Russia's long-term success in economic development is contingent on establishing a satisfactory environment for a high and sustained level of private investment. However, in the recent transition, Russia's economic and political progress has been hampered by a trilemma: a quasi-market system, a destructive bureaucracy and systemic corruption. These conditions had the effect not only of decelerating the rate of growth in domestic and foreign investment, but also of impeding Russia's advance into the global economy. 
Nesse sentido, mesmo após as reformas econômicas que culminaram em uma significativa transferência dos ativos públicos para o setor privado, a economia da Rússia ainda apresenta problemas estruturais que afetam negativamente o desempenho econômico do país. Entre as principais fragilidades domésticas, destacam-se: a reversão parcial do processo de privatização realizado na década de 1990, que aprofundou as relações de crony capitalism e reduziu a eficiência produtiva da economia da Rússia; deformidades no sistema financeiro que elevam os investimentos em setores de baixa competitividade em detrimento da alocação do crédito para atividades de maior eficiência e produtividade e; insegurança jurídica relacionada aos direitos de propriedade privada que acabam gerando desincentivos para a realização de novos investimentos produtivos que impliquem em um processo de maior diversidade produtiva da Rússia.

\section{Referências}

ALEKSASHENKO, Sergey. Russia's economic agenda to 2020. International Affairs 88: 1 (2012), p. 31-48.

ASLUND, Anders. Russia The Arduous Transition to a Market Economy. In: ASLUND, Anders; DJANKOV, Simeon. The great rebirth. Lessons from the Victory of Capitalism over Communism. Washington: Peterson Institute for International Finance, 2014. p. 89-112. ASTROV, Vasily. The Russian Oil Fund as a tool for stabilization and sterilization. Focus on European Integration, 01/2007. p. 167-177.

BANCO MUNDIAL. World Integrated Trade Solution. 2018. Disponível em: < http://wits. worldbank.org/CountrySnapshot/en/Russia > . Acesso: 15 jan. 2018.

CONNOLLY, Richard. In: KUHRT, Natasha; Feklyunina, Valentina (org.). Assessing Russia's Power: A Report. 2017. London: King's College London and Newcastle University, 2017. p. 21-24.

. Financial Constraints on the Modernization of the Russian Economy. Euroasian Geography and Economics, 2013, 52:3, p. 428-459.

CONNOLLY, Richard et al. Sanctions on Russia: Economic Effects and Political Rationales. London: ChatamHouse, 2015. Disponível em: < https://www.chathamhouse.org/sites/ files/chathamhouse/field/field_document/2015-06-30\%20Sanctions \% 20Event \% 20 Summary\%20final.pdf > . Acesso: 20 ago. 2017.

CONNOLLY, Richard; SENDSTAD, Cecilie. Russia's Role as an Arms Exporter. The Strategic and Economic Importance of Arms Exporters for Russia. London: Chatam House, 2017. (Research Paper) 
DJANKOV, Simeon. Russia's Economy under Putin: From Crony capitalism to State Capitalism. Washington: Peterson Institute for International Economics, 2015. (Policy Brief, 15-18).

EUROPEAN PARLIAMENT. Key aspects of Russia's current foreign and security policy. Brussels: Directorate-General For External Policies, 2015. (Policy Briefing).

FRIEDEN, Jeffry A. Capitalismo Global. História econômica e política do século XX. Rio de Janeiro: Jorge Zahar Editor, 2008.

GADDY, Clifford G.; ICKES, Barry W. Putin's rent management system and the future of addiction in Russia. In: OXENSTIERNA, Susanne (org). The challenges for Russia's politicized economic system. New York: Routledge, 2015. p. 11-32.

; ___.Russia’s Dependence on Resources. In: ALEXEEV, Michael; WEBER, Shlomo. The Oxford Handbook of the Russian Economy. Oxford: Oxford University Press, 2013a, p. 309-340.

; __. Resource Rents and the Russian Economy. Eurasian Geography and Economics, 2013b, 46:8, p. 559-583.

GURIEV, Sergei; TSYVINSKI, Aleh. Challenges Facing the Russian Economy after the Crisis. In: ASLUND, Anders; GURIEV, Sergei; KUCHINS, Andrew. Russia after the global economic crisis. Washington: Peterson Institute for International Economics, 2010. p. 9-38.

HANSON, Philip. The Russian economic puzzle: going fowads, backwards or sideways? International Affairs 83: 5 (2007), p. 869-889.

FUNDO MONETÁRIO INTERNACIONAL. World Economic Outlook Database. $2018 \mathrm{a}$. Disponível em: < https://www.imf.org/external/pubs/ft/weo/2017/01/weodata/ index.aspx > . Acesso: 15 jan. 2018.

. IMF Primary Commodity Prices. 2018b. Disponível em: < http://www.imf.org/ external/np/res/commod/index.aspx > . Acesso: 20 jan. 2018.

JOFFE, Josef. The Myth of America's Decline: Politics, economics and a half century of false prophecies. New York: W. W. Norton \& Company Inc., 2014.

KUBONIWA, Masaaki. The impact of oil prices, total factor productivity and institutional weakness on Russia's declining growth. In: OXENSTIERNA, Susanne (org). The challenges for Russia's politicized economic system. New York: Routledge, 2015. p. 113-127.

KUDRIN, Alexey; GURVICH, Evsey. A new growth model for the Russian economy. Russian Journal of Economic1 (2015), p. 30-54.

LETICHE, John M. Russia Moves into the Global Economy. New York: Routledge, 2007. OFER, Gur. Soviet Economic Growth: 1928-1985. Journal of Economic Literature, Vol. 25, No. 4 (Dec., 1987), p. 1767-1833.

ORGANIZAÇÃO INTERNACIONAL DO TRABALHO. Statistics and databases. 2018. Disponível em: < http://www.ilo.org/global/statistics-and-databases/lang--en/ index.htm > . Acesso: 11 jan. 2018. 
ROUBINI, Nouriel; MIHN, Stephen. A economia das crises. Rio de Janeiro: Editora Intrínseca, 2010.

SABITOVA, Nadia; SHAVALEYEVA, Chulpan. Oil and Gas Revenues on the Russian Federation: Trends and Prospects. 22 nd International Economic Conference IECS, 2015.

SCHWAB, Klaus. The Fourth Industrial Revolution. Geneva: World Economic Forum, 2016.

SHARMA, Ruchir. The Rise and Fall of Nations: Forces of change in the post-crisis world. London: W. W. Norton \& Company Ltd., 2016.

SHLEIFER, Andrei; TREISMAN, Daniel. A Normal Country: Russia After Communism. Journal of Economic Perspectives - Volume 19, Number 1 - Winter 2005, p. 151 - 174.

UNCTAD. Unctad Stat. 2018. Disponível em: < http://unctadstat.unctad.org/wds/ TableViewer/tableView.aspx > . Acesso: $01 \mathrm{fev.} 2018$.

VIOLA, Eduardo; LEIS, Héctor R. Sistema Internacional com Hegemonias das Democracias de Mercado. Desafios de Brasil e Argentina. Florianópolis: Editora Insular, 2007.

VIOLA, Eduardo, BASSO, Larissa. Brazilian energy-climate policy and politics towards low carbon development. Global Society, v. 29, n. 3, 2015.

VINHAS DE SOUZA, Lúcio. A Different Country. Russia’s Economic Resurgence. Brussels: Centre for European Policy Studies, 2007.

WOLF, Martin. A reconstrução do Sistema Financeiro Global. São Paulo: Editora Campus, 2008.

WORLD ECONOMIC FORUM. The Global Competitiveness Report 2016-2017. Geneva: World Economic Forum, 2017. 